\title{
AGRICULTURE LAND AFFORESTATION WITH FAST-GROWING WOODY CROPS: ECONOMIC EVALUATION ACCORDING TO YIELDS OF PREVIOUS EXPERIMENTAL TRIALS
}

\begin{abstract}
Kristaps MAKOVSKIS, Latvian State Forest Research Institute "Silava", Riga street 111, Salaspils, Latvia; kristaps.makovskis@ silava.lv (corresponding author)

Dagnija LAZDINA, Latvian State Forest Research Institute "Silava", Riga street 111, Salaspils, Latvia; kristaps.makovskis@silava.lv

Dina POPLUGA, Latvia University of Life Sciences and Technologies, Faculty of Economics and Social Development, Svetes street 18, Jelgava, Latvia dina.popluga@1llu.lv

European Union (EU) aims to increase the share of renewable energy in total energy consumption in the next decades. The main renewable resource, which is mentioned in the policy documents, is biomass, especially wood biomass. Wood biomass for energy purposes could be successfully acquired from fast-growing woody plantations, growing on non-used agricultural lands. In Latvia, in 2019 were around 250000 ha non-used agriculture land and part of it could be used for plantation growing. In Latvia, suitable woody species for use in plantations are willow, hybrid aspen, and grey alder. For economic calculations plantation site preparation before planting, planting, management, and biomass harvest costs were calculated, as well as revenues from selling biomass. In total 7 different plantation models were evaluated. Comparing the economic indicators for fast-growing woody crop plantation models during their cultivation and applying a discount rate of $7.63 \%$, average service costs and product selling prices for the period 2015-2019, and under the existing plantation support system in 2021, intensively managed willow plantations, extensively managed willow plantations and hybrid aspen agroforestry plantations show positive accumulated cash flow. Hybrid aspen woody plantations and plantation forest, and grey alder energy wood and woody plantations show a negative accumulated cash flow, and their establishment in 2021 does not pay off. Factors that mostly affect plantation cash flow and therefore economic return are the biomass selling price and harvested biomass volume.
\end{abstract}

Keywords: SRC, willow plantations, hybrid aspen plantations, grey alder plantations, fast-growing woody crop plantations.

\section{INTRODUCTION}

Renewable energy resources in energy production in the last decades is an important and widely discussed issue at national, regional, and global levels. Until the $19^{\text {th }}$ century, society mainly had used renewable resources for energy production, while in the $20^{\text {th }}$ century, primarily non-renewable resources (Tillman, 1978, Quaschning, 2010). Resource use should be financially justified, environmentally friendly, socially responsible, and politically regulated in terms of accessibility and security (Arunachalam, Bharadwaj, 2012). In response to the future climate change challenges, nonrenewable resources will increasingly be replaced by renewable resources. The use of renewable energy generates savings in greenhouse gas emissions, ensures food security, reduces environmental degradation, and supports certain ecosystem services. Its use can also bring social, environmental, and economic benefits while ensuring rural areas' development. Biomass cultivation solves several problems: the use of unused agricultural land, the reduction of unemployment, and rural development (Thornley, 2006; Upham, Shackley, 2007). Biomass has become a significant resource for renewable energy production in many countries.

In Latvian conditions, biomass can be successfully obtained in fast-growing woody crop plantations by installing them in unused agricultural land. Based on the Rural Support Service (RSS) data, in 2019, were 2.2 million hectares of agricultural land, of which 256180 hectares were uncultivated. Some of these lands could be used for fast-growing woody crop plantations. Previous studies in Latvia show, that based on growth conditions, fast-growing woody crop species suitable for Latvian conditions are willow (Salix spp.), hybrid aspen (Populus spp.), and grey alder (Alnus incana L.) (Lazdina, 2009; Daugaviete et al, 2015; Zeps, 2017).

Willows are considered promising species used in fast-growing woody crop plantations on agricultural land in the Northern European region and shows a positive $\mathrm{CO}_{2}$ balance (Hall, House, 1994, Gonzalez-Garcia et al., 2012). Willow energy wood plantations are the primary use of willow and are the most widely used woody crop species in energy wood plantations in Europe. The average productivity of willow plantations in Latvian conditions is 8-12 odt. ha ${ }^{-1}$ year, in some cases up to 30 odt. ha ${ }^{-1}$ year (Lazdina, 2009). Some previous studies suggest that willow plantation growing is economically justified if the biomass growth is at least $8-9$ odt. ha $^{-1}$ year (Rosenqvist, Dawson,

Copyright (C) 2021 The Authors. Published by Vytautas Magnus University. This is an open-access article distributed under the terms of the Creative Commons Attribution License (CC BY 4.0), which permits unrestricted use, distribution, and reproduction in any medium, provided the original author and source are credited. 
2005). Willow plantations have high yields in a relatively short period (3-5 years) and easily regenerate from the shoots after harvesting. Depending on the type of use, hybrid aspen plantations can be used as pulpwood, sawlog, or agroforestry plantations. Hybrid aspen wood fibers could be used in paper productions (Zeps et al., 2012). Mostly in Latvia are grown saw log plantations, where the main product is sawlog. Agroforestry plantations in Latvia are grown only for scientific reasons and are not widely used. Grey alder in the boreal forest zone is considered one of the fastestgrowing tree species from which it is possible to obtain timber or use it as a renewable energy resource production of energy wood (Daugaviete, 2010). Studies about fast-growing woody crop plantations in Latvia mostly were more conducted on growth aspects, not much of economics.

The study aimed to calculate the economic return for growing biomass in willow, hybrid aspen, and grey alder fast-growing woody crop plantations in Latvia and show that growing fast-growing woody crop plantations on unused agricultural land is an economically justified way of land management and would promote the production of wood biomass in Latvia/

\section{MATERIAL AND METHODS}

In this study 3 different woody crop species were selected for the calculations: willow, hybrid aspen, and grey alder and for every species, several growing models were evaluated.

For willow plantations, extensive and intensive growing models were evaluated according to yields gathered in experimental trials of LSFRI Silava (unpublished data from projects: Elaboration of models...2010). The extensive willow management model is used in areas with a total area size up to 5 hectares or in cases where specialized harvesting machines are not available. The plantation life span is 25 years, one rotation period is 4 years, the first harvest is obtained in the $5^{\text {th }}$ year of the plantation, and 6 biomass harvests are carried out. The area is fertilized before planting with fertilizers and is not fertilized during further management of the plantation. In the extensive model willow harvesting is done using handheld power tools - chainsaw or brushcutter. The cut stem transport to the edge of the field is performed using a small class forestry tractor or an adapted agricultural tractor with a trailer adapted to transport the stems. Stem chipping is performed on the field's edge with mobile chippers, filling the biomass into delivery machines. The plantation product is wood chips.

The intensive willow management model is used in areas with a total area size of over 5 ha or in cases where specialized harvest machines are available. Soil is improved with mineral fertilizers before planting and with wood ash after each biomass harvest. The plantation life span is 25 years, one rotation period is 3 years, the harvest is obtained in the $4^{\text {th }}$ year of the plantation, and 8 biomass harvests are carried out. In an intensive willow management model, specialized harvest machines are used, where the harvesting is carried out together with chipping. The chipped biomass is stored in open piles on the edge of the field for some time, where it dries before further transportation. The plantation product is wood chips.

For hybrid aspen plantations - woody, agroforestry plantations, and plantation forest management models were evaluated.

Hybrid aspen woody plantation rotation is 15 years (the plantation is grown with 2 rotations), and the total lifespan of the plantations is 30 years, after which the plantation is renewed. Plantation products are pulpwood, firewood, and wood chips.

The hybrid aspen agroforestry plantation rotation period is 15 years (the plantation is grown for 2 rotations), and the whole plantation lifespan is 30 years, after which the plantation is renewed. Agroforestry plantation involves growing trees and grasses simultaneously in the same area for a certain period. After a certain period, usually 5 years, the grasses are not reseeded, and only trees are grown till biomass harvest. For the first 5 years of the study, reed canary grass (Phalaris arundinacea L.) is grown together with hybrid aspen, seeds harvested and sold. Plantation products are pulpwood, firewood, wood chips, and reed canary grass seeds for the first 5 years.

The hybrid aspen plantation forest rotation period is 20 years (the plantation is grown for 2 rotations), and the total plantation lifespan is 40 years, after which the plantation is renewed. Plantation products are sawlogs, pulpwood, firewood, and wood chips.

For grey alder plantations - woody and energy plantations were evaluated. Grey alder woody plantation rotation period is 15 years (the plantation is grown for 2 rotations), and the total lifespan of the plantations is 30 years, after which the plantation is restored. Plantations are grown to obtain pulpwood and firewood.

Grey alder wood energy plantation rotation period is 15 years (the plantation is grown for 2 rotations), and the total lifespan of the plantations is 30 years, after which the plantation is restored. Plantations are grown to obtain wood chips.

Soil preparation before planting and reed canary grass seed harvesting costs were taken from Latvian Rural Advisory and Training Centre agriculture service costs database in period 2015-2019. Hybrid aspen and grey alder wood biomass is harvested using logging techniques. Agricultural machinery is used for reed canary grass seed harvesting in agroforestry plantations. The costs of preparation, delivery, and transportation of timber used in the study are from Central Statistical Bureau Republic of Latvia (CSB) database “Average costs of logging, 2015-2019”.

All service costs and prices in the calculations are taken as average costs for the period 2015-2019, to smooth out short-term cost and price changes. All data, if possible, were taken from statistic reports and official sites. For the economic calculations - soil preparation before planting, planting, plantation management, and biomass harvest operation costs were calculated. Plantation revenues were from timber and wood chips selling in the market, as well EU support payment to farmers under the Single Area Payment Schemes (SAPS), what could be received for woody crop plantation growing, if the rotation period did not exceed 5 years or for the first 5 years if the rotation period is longer. 


\section{RESULTS AND DISCUSSION}

Soil preparation before planning costs consists of overgrowth removal (290 EUR ha-1), herbicide costs (23.5 EUR ha ${ }^{-1)}$, mineral fertilizers costs (173.00 EUR ha-1), plowing (48.64 EUR ha-1), herbicide transport (16.00 EUR $\mathrm{ha}^{-1}$ ), herbicide spraying (19.89 EUR ha-1), discing (31.46 EUR ha $\left.{ }^{-1}\right)$, cultivation (30.85 EUR ha-1), fertilizer transport (16.00 EUR ha ${ }^{-1}$ ) and fertilizer spreading (18.10 EUR ha-1), in total 667.45 EUR ha' $\mathrm{ES}^{-1}$ Soil preparation before planting costs are the same for all tree species and management models.

Planting costs differ between woody crop species and management models because plantation density and seedling price is different as well planting service costs. In both willow plantation models tree density is 13000 cuttings $\mathrm{ha}^{-1}$ and price 0.05 EUR per cutting, and planting service costs $215.00 \mathrm{EUR} \mathrm{ha}^{-1}$. Hybrid aspen seedling price is 0.8 EUR, woody plantation and agroforestry plantation density is 1100 seedlings ha ${ }^{-1}$, and planting service costs 107.02 EUR ha-1 ${ }^{-1}$ Hybrid aspen tree plantation density is 800 seedlings ha-1 and planting service costs $77.83 \mathrm{EUR}^{-1}$ ha In hybrid aspen agroforestry plantations, reed canary grass seed price is $6.47 \mathrm{EUR} \mathrm{kg}$, used amount $5 \mathrm{~kg} \mathrm{ha}^{-1}$ and sowing service costs $28.82 \mathrm{EUR} \mathrm{ha}^{-1}$. Grey alder seedling price is $0.24 \mathrm{EUR}$, seedling density in woody plantation and energy plantations 1100 seedlings ha ${ }^{-1}$ and planting service costs 107.02 EUR ha $^{-1}$.

Plantation management costs include fertilizer re-incorporation in soil (transport $16.00 \mathrm{EUR} \mathrm{ha}^{-1}$, spreading 18.10 EUR ha ${ }^{-1}$ ), cutback (107.49 EUR ha-1), agrotechnical tending (107.49 EUR ha-1), administrative costs, and land tax. After first fertilization, where mineral fertilizer was used, in the next fertilizations wood ash is used. Wood ash is by-product in cogeneration stations and boiler houses, therefore it is free of charge, only transportation costs should be covered.

The calculations in the study assume that the land is owned and no rent is paid. The administrative costs in the study are assumed to be 5.00 EUR ha-1 year and land tax is $7.67 \mathrm{EUR} \mathrm{ha}^{-1}$. Plantation management costs differ depending on used woody crop species and management model.

In the willow extensive model, the biomass increase in one year is 54.01 loose $^{3} \mathrm{ha}^{-1}$ of wood chips, mowing occurs once in 4 years, where the total amount of wood chips in one mowing is 216.05 loose $\mathrm{m}^{3} \mathrm{ha}^{-1}$. In the intensive model, the biomass growth in one year is 61.73 loose $\mathrm{m}^{3} \mathrm{ha}^{-1}$ of wood chips. The annual biomass increase in the intensive management model is higher than in the extensive model, as the plantations are fertilized with wood ash after each biomass harvest, promoting the growth of biomass. Willow mowing occurs once in 3 years, where the total amount of wood chips in one mowing is 185.19 loose $\mathrm{m}^{3} \mathrm{ha}^{-1}$. In extensive willow model harvest is done with the manual method, where costs are 4.29 EUR loose $\mathrm{m}^{3} \mathrm{ha}^{-1}$. In intensive willow model harvest is done with mechanized harvest method, where costs are 3.00 EUR loose $\mathrm{m}^{3} \mathrm{ha}^{-1}$. The research data willow harvest costs are from consultations with the representatives of the companies SIA "Salixenergi Baltic" and SIA "Ecomark", which is engaged in the cultivation and management of willow plantations in Latvia.

The volume of wood obtained in 15 years old hybrid aspen woody and agroforestry plantations is $135 \mathrm{~m}^{3}$ ha of roundwood (pulpwood and firewood) and 27 loose $\mathrm{m}^{3} \mathrm{ha}^{-1}$ woodchip. The volume of reed canary grass seeds knocked down in an agroforestry plantation in one year is $163 \mathrm{~kg} \mathrm{ha}^{-1}$. The volume of wood obtained in 20 years old hybrid aspen plantations is $260 \mathrm{~m} 3 \mathrm{ha}^{-1}$ of roundwood (sawlogs, packing blocks, pulpwood, and firewood) and 54 loose $\mathrm{m}^{3}$ ha ${ }^{-1}$ woodchip. Data on the yield indicators of aspen hybrids (at the age of 15 and 20) and the distribution of roundwood assortment were obtained from previous studies performed by LSFRI Silava (Zeps, 2017).

The volume of wood obtained in 15 years old grey alder plantations is $120 \mathrm{~m}^{3}$ ha of roundwood (pulpwood and firewood) and 27 loose $\mathrm{m}^{3} \mathrm{ha}^{-1}$ woodchip. In grey alder energy wood plantations, it is assumed, that the wood is not sold as roundwood, but is chipped and sold as woodchips. Converting from the roundwood to woodchips, the total amount of woodchips is 351 loose $\mathrm{m}^{3} \mathrm{ha}^{-1}$. Data on the yield indicators of grey alder and the distribution of roundwood assortment were obtained from previous studies. (Daugaviete et al., 2015)

Costs for timber preparation $5.85 \mathrm{EUR} \mathrm{m}^{3}$, timber delivery from felling area to road $4.72 \mathrm{EUR} \mathrm{m}^{3}$, timber transportation from the road to the point of purchase $6.23 \mathrm{EUR} \mathrm{m}^{3}$ and chipping $2.50 \mathrm{EUR}$ loose $\mathrm{m}^{3}$. Costs for reed canary grass threshing are 60.00 EUR ha-1, drying 0.06 EUR kg, cleaning 0.12 EUR kg, and transport 38.00 EUR for distance up to $50 \mathrm{~km}$.

Revenues come from selling fast-growing woody crop plantation products. Additional revenues in Hybrid aspen agroforestry plantations (for the first 5 years) comes from selling reed canary grass seeds. Reed canary grass seeds selling price is 3 EUR kg. The average prices of deciduous tree roundwood and wood chips in period 2015-2019, come from the CSB and "Latvianwood" database. Used prices: saw $\log 46.88 \mathrm{EUR} \mathrm{m}^{3}$, container block $37.02 \mathrm{EUR}^{3}$, pulpwood 28.84 EUR $\mathrm{m}^{3}$, firewood $24.37 \mathrm{EUR} \mathrm{m}^{3}$, woodchips $9.38 \mathrm{EUR}$ loose $\mathrm{m}^{3}$. Additional revenues come from SAPS payment what is $110.07 \mathrm{EUR} \mathrm{ha}^{-1}$ year.

The payback period, Net Present Value (NPV), and internal rate of return (IRR) were calculated for evaluating and comparing all fast-growing woody crop plantation management models, Table 1.

Used discount rate in the economic calculations is $7.63 \%$, which is taken from the Republic of Latvia Treasury calculator - investments in agriculture.

The intensive willow management model shows a faster payback period of 6.8 years, which is 2.1 years faster than the extensive willow management model with a payback of 8.9 years. A faster payback period guarantees a faster return on investment, which is an essential factor when choosing to set up fast-growing woody crop plantations or choosing a willow plantation management model. For both willow models, the payback period is shorter than the growing time of willow plantations ( 25 years), which indicates the economic profitability of willow plantations. 
Table 1. Fast growing woody crop plantation economic indicators during plantation lifespan in Latvia

\begin{tabular}{|l|c|c|c|}
\hline \multicolumn{1}{|c|}{ Plantation type } & Payback period, years & NPV, EUR ha ${ }^{-1}$ & IRR, $\%$ \\
\hline Willow extensive management model & 8.9 & 1561.91 & 15.0 \\
\hline Willow intensive management model & 6.8 & 2576.64 & 19.3 \\
\hline Hybrid aspen agroforestry plantation & 17.4 & 215.31 & $9.1 \%$ \\
\hline Hybrid aspen plantation forest & No payoff & -484.22 & $6.4 \%$ \\
\hline Hybrid aspen woody plantation & No payoff & -1184.63 & $2.6 \%$ \\
\hline Grey alder woody plantation & No payoff & -490.84 & $4.3 \%$ \\
\hline Grey alder energy wood plantation & No payoff & -596.14 & $3.1 \%$ \\
\hline
\end{tabular}

Applying the discount rate of $7.63 \%$, the cumulative NPV cash flow for extensively managed willow plantations during their lifetime is $1561.91 \mathrm{EUR} \mathrm{ha}^{-1}$, while for intensively managed willow plantations $2576.64 \mathrm{EUR} \mathrm{ha}^{-1}$, which is 65\% more. Several authors (Kuemmel et al., 1998; Goor et al., 2000; Webb et al., 2009; Konstantinaviciene et al., 2020) have used the NPV method to characterize different types of biomass production plantations. When choosing between different alternatives, preference is given to the project with the highest NPV value. According to Vandenhove et al. (2002) and Tharakan et al. (2005), when evaluating fast-growing woody plantations in parallel with the value of NPV, it is useful to calculate the IRR. The value shows at which discount rate NPV $=0$. The results show that the lowest discount rate at which it pays to install intensively managed willow plantations in Latvia is $19.3 \%$, and extensively managed plantations $15 \%$.

Hybrid aspen plantation forests and woody plantations do not earn back invested money in their establishment compared to Hybrid aspen agroforestry plantations, which are profitable with payback period of 17.4 years. This is possible due to growing reed canary grass parallel to trees in the first 5 years, where additional revenues from selling reed canary grass seeds are 362 EUR ha $^{-1}$. This income can be obtained at the beginning of the plantation lifespan, so that part of the investment can be recouped quicker than in traditional tree growing where the first income is after 15-20 years.

The hybrid aspen agroforestry plantation shows a positive NPV value of $215.31 \mathrm{EUR} \mathrm{ha}^{-1}$, which indicates the recovery of the initial investment by choosing to grow agroforestry plantation using a discount rate of $7.63 \%$. The woody plantation and the plantation forest show a negative NPV value, which means that these plantations cultivation is not economically justified. The calculated IRR value concludes that the lowest discount rate at which it pays to establish agroforestry plantations is $9.1 \%$, plantation forests $6.2 \%$ and woody plantations $2.6 \%$. In Estonian hybrid aspen plantation IRR ranges from 5.7-8.1\%, while in Sweden, around 10\% (Rytter et al., 2011; Tullus et al., 2012). The obtained results state that the cultivation of hybrid aspen plantations in the Nordic countries is an economically viable use of agricultural land.

NPV cash flow over a lifespan for a grey alder woody plantation is $-490.84 \mathrm{EUR} \mathrm{ha}^{-1}$ and for an energy wood plantation -596.14 EUR ha $\mathrm{a}^{-1}$. The performed calculations allow us to establish that regardless of the type of wood product (timber or wood chips), grey alder plantations show a negative cash flow. Both models of grey alder plantation do not earn money invested in establishment, management, and harvesting. For both plantation models, the NPV value is negative, which means that these plantations are not economically justified.

Accumulated discounted cash flow value is most affected by the timber, wood chips prices, and harvested biomass volume. Factors, that influence timber price changes, are economic downturns, price changes of substitutes (cement, metal), climate changes, construction industry stagnation, changes in oil prices, and restrictions on felling (Suchomel et al., 2012). It is not excluded, that such changes could occur in near future and made fast-growing woody crop plantations more profitable. Harvested biomass volumes, especially in fast-growing woody crop plantations, can be increased by regular and thoughtful fertilization, where studies show, that in Latvian conditions most suitable fertilizers are wood ash and wastewater sludges (Lazdina, 2009, Petaja et al., 2018). Additional studies are necessary, to test wood ash fertilization and different fertilization mixes with wood ash, to assess the impact on biomass increase in plantations.

\section{CONCLUSIONS}

Comparing the economic indicators for fast-growing woody crop plantation models during their cultivation and applying a discount rate of 7.63\%, average service costs and product selling prices for period 2015-2019, and under the existing plantation support system in 2021, intensively managed willow plantations, extensively managed willow plantations and hybrid aspen agroforestry plantations show positive accumulated discounted cash flow. Hybrid aspen woody plantations, plantation forest and grey alder energy wood and woody plantations show a negative accumulated cash flow, and their establishment in 2021 does not pay off. Factors that affect plantation cash flow and therefore economic return are plantation product selling price and harvested biomass volume. Product selling prices are affected by market and plantation owner has limited impact on them, however, plantation biomass volumes could be directly affected by plantation owner by choosing right management plan. Plantation fertilization and increasing of organics in mineral soils is one of the ways, how to increase biomass volume from the plantation. One of the most accessible fertilizer in Latvia, that could be used in fast-growing woody crop plantations is wood ash, also peat as organic substance is available. Further studies are necessary to evaluate and test different wood ash mixes with organic materials for plantation fertilization. 
Acknowledgement. Elaboration of innovative White Willow-perennial grass agroforestry systems on marginal mineral soils improved by wood ash and less demanded peat fractions amendments. 1.1.1.1/19/A/112 ERAF.

\section{REFERNECES}

1. Arunachalam V.S., Bharadwaj A. 2012. The Global energy landscape and energy security. In: Fundamentals of Materials for Energy and Environmental Sustainability. Editors: Ginley D.S., Cahen D. Cambridge University Press, New York.

2. Daugaviete M. 2010. Biomasas uzkrāššāas baltalkšṇa (Alnus incana (L.) Moench.) jaunaudzēs. Mežzinātne, Vol/ 21, pp. 16-30. (In Latvian).

3. Daugaviete M., Bārdulis A., Daugavietis U., Lazdina D., Bārdule A. 2015. Potential of producing wood biomass in shortrotation grey alder (Alnus incana (L.) Moench) plantations on agriculture lands. Nordic View to Sustainable Rural Development, NJF 25th Congress, pp. 394-399.

4. Elaboration of models for establishment and management of multifunctional plantations of short rotation energy crops and deciduous trees. No 2010/0268/2DP/2.1.1.1.0/10/APIA/VIAA/118 http://www.agroforestrylatvia.com/2013/12/karkluplantaciju -ierikosanas-izmaksu.html

5. Gonzalez-Garcia S., Bacenetti J., Murphy J.R., Fiala M. 2012. Present and future environmental impact of poplar cultivation in the Po Valley (Italy) under different crop management systems. Journal of Cleaner Production, Vol. 26, pp. 56-66. https://doi.org/10.1016/j.jclepro.2011.12.020

6. Goor F., Jossart J.M., Ledent J.F. 2000. ECOP: an economic model to assess the willow short rotation coppice global profitability in a case of small scale gasification pathway in Belgium. Environmental Modelling \& Software, Vol. 15(3), pp. 279-292. https://doi.org/10.1016/S1364-8152(00)00014-1

7. Hall D.O., House J.I. 1994. Trees and biomass energy: carbon storage and/or fossil substitution? Biomass and Bioenergy, Vol. 6, pp. 11-30. https://doi.org/10.1016/0961-9534(94)90081-7

8. Konstantinaviciene J., Skema M., Stakenas V., Aleinikovas M., Silinskas B., Varnagiryte-Kabasinskiene I. 2017. Above-ground Biomass of Willow Energy Plantations in Lithuania: Pilot Study. Baltic Forestry, Vol. 23(3), pp. 658-665.

9. Kuemmel B., Langer V., Magid J., De Neergaard A., Porter J.R. 1998. Energetic, economic and ecological balances of a combined food and energy system. Biomass Bioenergy, Vol. 15(4-5), pp. 407-416. https://doi.org/10.1016/S09619534(98)00047-6

10. Lazdina D. 2009. Usage of Sewage Sludge in Willow Plantations. Resume of the PhD Paper for the scientific degree of Dr. silv. in Forest Ecology and Silviculture. Jelgava, Latvia, pp. 57.

11. Petaja G., Okmanis M., Makovskis K., Lazdiņa D., Lazdiņ̌s A. 2018. Forest fertilization: Economic effect and impact on GHG emissions in Latvia. Baltic Forestry, Vol. 24(1)., pp. 9-16.

12. Quaschning V. 2010. Renewable Energy and Climate Change. IEEE Press, John Wiley \& Sons, West Sussex, United Kingdom. https://doi.org/10.1002/9781119994381

13. Rosenqvist H., Dawson M. 2005. Economics of willow growing in Northern Ireland. Biomass and Bioenergy, Vol. 28, pp. 7-14. https://doi.org/10.1016/j.biombioe.2004.06.001

14. Rytter L., Johansson T., Karsčić A., Weih M. 2011. Investigation for a Swedish Research Program on the Genus Populus. The Forestry Research Institute of Sweden (Skogforsk), Arbetsrapport Nr 733.

15. Suchomel J., Gejdoš M., Ambrušová L., Šulek R. 2012. Analysis of price changes of selected roundwood assortments in some Central Europe countries. Journal of Forensic Sciences, Vol. 58, pp. 483-491. https://doi.org/10.17221/98/2011-JFS

16. Tharakan P.J., Volk T.A., Lindsey C.A., Abrahamson L.P., White E.H. 2005. Evaluating the impact of three incentive programs on the economics of cofiring willow biomass with coal in New York State. Energ Policy, Vol. 33(3), pp. 337-347. https://doi.org/10.1016/j.enpol.2003.08.004

17. Thornley P. 2006. Increasing biomass based power generation in the UK. Energy Policy, Vol. 34(15), pp. 2087-2099. https://doi.org/10.1016/j.enpol.2005.02.006

18. Tillman D.A. 1978. Wood as an Energy Source, New York.

19. Tullus A., Lukason O., Vares A., Padari A. Lutter R., Tullus T., Karoles K., Tullus H. 2012. Economics of Hybrid Aspen (Populus tremula L. $\times$ P. tremuloides Michx.) and Silver Birch (Betula pendula Roth.) Plantations on Abandoned Agricultural Lands in Estonia. Baltic Forestry, Vol. 18(2), pp. 288-298.

20. Upham P., Shackley S. 2007. Local public opinion of a proposed 21.5 MW(e) biomass gasifier in Devon: questionnaire survey results. Biomass and Bioenergy, Vol. 31, pp. 433-441. https://doi.org/10.1016/j.biombioe.2007.01.017

21. Vandenhove H., Goor F., O'Brien S., Grebenkov A., Timofeyev S. 2002. Economic viability of short rotation coppice for energy production for reuse of caesium-contaminated land in Belarus. Biomass and Bioenergy, Vol. 22(6), pp. 421-431. https://doi.org/10.1016/S0961-9534(02)00020-X

22. Webb J., Cook P., Skiba U., Levy P., Sajwaj T., Parker C. 2009. Investigation of the economics and potential environmental impacts of the production of short rotation coppicing on poorer quality land. Oxfordshire: AEA group; 2009 Jan. Report No. ED45623 [skatīts 26.08.2019]. Pieejams.

23. Zeps M. 2017. Apšu hibrīdu (Populus tremuloides Michx. $\times$ Populus tremula L.) audzēšanas potenciāls Latvijā. Promocijas darba kopsavilkums Dr.silv. zinātniskā grāda iegūšanai. 51 pp. (In Latvian)

24. Zeps M., Šāble I., Grīnfelds U., Jansons Ā., Irbe I., Treimanis A. 2012. Apšu hibrīdu koksnes un sulfātselulozes škiedru īpašības 20 gadu vecumā. Mě̌zinātne, Vol. 59, pp. 145-154. (In Latvian) 